\title{
PENGARUH PARTISIPASI ANGGARAN, KOMITMEN ORGANISASI, MOTIVASI TERHADAP KINERJA MANAJERIAL PADA PERUSAHAAN PT. ZZZ
}

\author{
Jonathan \\ Program Studi Magister Manajemen Universitas Tarumanagara \\ johnmatthew@zoho.com
}

\begin{abstract}
This research aims to determine the effect of budget participation, organization's commitment and motivation toward managerial performance. The population included was employees in beverage company in Jakarta. Sampling was collected by using a purposive sampling method and the number of sample obtained 139 samples that meet the criteria and free from outliers. In addition to the above primary data, this study also collected secondary data from literatures and studies. Multiple Regression analysis was used as analytical technique. The result showed that budget participation, organization's commitment and motivation jointly have significant positive effect on managerial performance. The study therefore recommends among others that all those presently involved in the implementation of budgets should be educated on the purpose and objectives of budgetary control and that lower level managers and staffs who are directly involved in the implementation of the budget should be co-opted into the budget setting process.
\end{abstract}

Keywords: Budget Participation, Managerial Performance, Commitment, Motivation

\section{PENDAHULUAN}

Kinerja manajerial merupakan salah satu faktor penting yang dapat digunakan meningkatkan efektivtas perusahaan. Kinerja manajerial dapat disebut sebagai kinerja atau prestasi kerja karyawan, dimana kinerja atau prestasi kerja karyawan pada dasarnya adalah hasil karya seorang karyawan selama periode tertentu dibandingkan dengan berbagai kemungkinan, seperti : standar, target atau kriteria yang telah ditentukan terlebih dahulu dan telah disepakati bersama (Mulyadi, 2001). Salah satu komponen penting dalam perencanaan adalah anggaran. Anggaran adalah suatu rencana kuantitatif (satuan jumlah) periodik yang disusun berdasarkan progam yang telah disahkan, sebagai alat manajemen dalam mencapai tujuan (Nafarin, 2008). Anggaran merupakan elemen sistem pengendalian manajemen yang berfungsi sebagai alat perencanaan dan pengendalian agar manajer dapat melaksanakan kegiatan organisasi secara lebih efektif dan efisien (Sarjana et.al 2012).

Motivasi adalah keinginan seseorang dalam berusaha untuk melaksanakan suatu tugas atau pekerjaan dengan baik (Mitchell, 1982 dalam Riyadi, 2007). Motivasi sangat mempengaruhi cara kerja seorang manajer, karena partisipasi dalam penyusunan anggaran lebih efektif apabila seorang manajer memiliki motivasi yang tinggi, sehingga kinerja akan meningkat (Riyadi, 1998 dalam Moktamar, 2008). Dalam dunia kerja sendiri, komitmen seseorang terhadap organisasi atau perusahaan seringkali menjadi penting dan bukanlah suatu hal yang terjadi secara sepihak. Jika iklim kerja dalam organisasi tersebut kurang menunjang, misalnya fasilitas kurang, maka akan menyebabkan komitmen seseorang terhadap organisasi tersebut menjadi menurun. Sehingga dapat menimbulkan berbagai gejolak seperti korupsi, tindak kriminal, pengunduran diri dan sebagainya. Dengan kata lain komitmen organisasi menyiratkan hubungan pegawai dengan perusahaan atau organisasi secara aktif.

Penelitian ini bermaksud meneliti kembali pengaruh partisipasi anggaran terhadap kinerja manajerial dengan mengacu pada penelitian Gandasuli et al. (2009). Namun terdapat 
perbedaan pada penelitian ini, lokasi penelitian sebelumnya dilakukan di Makasar, sedangkan penelitian ini dilakukan di Jakarta. Selain itu ditambah dua variabel yaitu motivasi dan komitmen organisasi yang menurut Sarjana et al. (2012) menemukan bahwa motivasi berpengaruh positif terhadap hubungan pertisipasi anggaran dengan kinerja manajerial

\section{PERUMUSAN HIPOTESIS}

\section{Partisipasi Anggaran dan Kinerja Manajerial}

Othman dan haryanti (2012) menyatakan bahwa penyusunan anggaran secara partisipatif diharapkan dapat meningkatkan kinerja, yaitu ketika suatu tujuan dirancang dan secara partisipasi disetujui bersama, maka baik pimpinan maupun bawahan akan menginternalisasikan tujuan yang ditetapkan dan memiliki rasa tanggung jawab pribadi untuk mencapainya karena mereka ikut terlibat dalam penyusunan anggaran. Dengan adanya keterlibatan atau partisipasi dalam penyusunan anggaran, akan memacu peningkatan moral dan inisiatif bagi mereka yang mengembangkan ide dan informasi pada seluruh tingkat manajemen, meningkatkan kekompakan tim yang kemudian meningkatkan kerjasama antar individu dalam pencapaian tujuan, terbentuknya intenalisasi kelompok yaitu penyatuan tujuan individu dan organisasi, menghindari tekanan dan kebingungan dalam melaksanakan pekerjaan dan manajer menjadi tanggap terhadap masalah-masalah sub unit tertentu serta memiliki pemahaman yang lebih baik tentang ketergantungan antar departemen sehingga akan meningkatkan kinerja baik pimpinan maupun subordinat untuk dapat mencapai sasaran/target yang telah ditetapkan dalam anggaran. Berdasarkan uraian di atas, hipotesis pengaruh partisipasi anggaran terhadap kinerja manajerial adalah:

H1: Terdapat pengaruh positif partisipasi anggaran terhadap kinerja manajerial.

\section{Komitmen Organisasi dan Kinerja Manajerial}

Othman dan Haryanti (2012) menganalisis komitmen organisasi dalam pengaruhnya pada hubungan partisipasi anggaran dan kinerja. Hasil penelitiannya menyatakan bahwa komitmen organisasi dan kinerja memiliki hubungan positif. Semakin tinggi komitmen terhadap organisasi, manajer semakin merasa memiliki organisasi dan merasa dirinya adalah bagian dari tempatnya bekerja sehingga membuat manajer akan memberikan hasil upaya dan kinerja yang lebih baik

Rumasukun, et al (2015) menganalisis komitmen organisasi dalam pengaruhnya pada hubungan partisipasi anggaran dan kinerja. Hasil penelitiannya menyatakan bahwa komitmen organisasi dan kinerja memiliki hubungan positif dan signifikan. Semakin tinggi komitmen terhadap organisasi, manajer merasa memiliki organisasi tempatnya bekerja sehingga membuat manajer akan memberikan hasil upaya dan kinerja yang lebih baik. Hipotesis pengaruh komitmen organisasi terhadap kinerja manajerial adalah sebagai berikut:

H2 : Terdapat pengaruh positif komitmen organisasi terhadap kinerja manajerial

\section{Motivasi dan Kinerja Manajerial}

Motivasi mempunyai pengaruh terhadap kinerja manajerial. Untuk mengetahui apakah motivasi berpengaruh terhadap kinerja manajerial, dapat dilihat pada motivasi pada manajer yang berpartisipasi dalam penyusunan anggaran. Jika dijelaskan motivasi tinggi kinerja manajerial tinggi dan motivasi rendah kinerja manajerial rendah. Penyusunan anggaran dimaksudkan bukan hanya untuk menyajikan informasi mengenai rencana keuangan yang berisi tentang biaya-biaya ndan pendapatan pusat-pusat pertanggungjawabkan suatu organisasi bisnis, tetapi juga merupakan suatu alat untuk pengendalian,koordinasi,komunikasi, evaluasi kerja, dan motivasi 
Keterkaitan antara motivasi dengan kinerja manajerial telah banyak dilakukan oleh penelitian-penelitian terdahulu, dan hasilnya dapat disimpulkan adalah adanya hubungan yang positif Moheri Dan Arifah (2015). Menurut Rumasukun, et al (2015) hasil penelitiannya menunjukkan bahwa motivasi mempuyai pengaruh positif terhadap kinerja manajerial.

H3 : Terdapat pengaruh positif motivasi terhadap kinerja manajerial

\section{METODE PENELITIAN}

\section{Sumber data dan cara pengumpulan sampel}

Sumber data dalam penelitian ini adalah data primer dan sekunder. Data primer dikumpulkan dari daftar pertanyaan yang diperoleh dari karyawan PT. ZZZ. Sampel diambil secara acak sebanyak 139 responden dari berbagai divisi di dalam perusahaan. Sedangkan data sekunder merupakan data penunjang penelitian yang diperoleh dari berbagai sumber untuk melengkapi data primer. Sumber data sekunder berasal dari studi pustaka baik berupa buku dan informasi yang ada hubungannya dengan masalah yang diteliti.

\section{Metode Analisis}

Metode analisis untuk menjawab penelitian ini yakni dengan menggunakan analisis statistik regresi linier berganda. Sedangkan alat untuk melakukan perhitungan regresi berganda yakni dengan menggunakan software Microsoft Excel yaitu SPSS. Sebelum dilakukan analisis regresi, data yang dikumpulkan diuji terlebih dahulu tingkat validitas dan reliabilitasnya. Kemudian dilakukan uji asumsi klasik untuk mengetahui apakah model yang ditetapkan memenuhi persyaratan OLS. Uji asumsi klasik terdiri dari:

a. Uji Normalitas

b. Uji Autokorelasi

c. Uji Heterokedastisitas

d. Uji Multikolinearitas

Model dari regresi berganda secara statistik dapat dirumuskan sebagai berikut:

$\hat{\mathrm{Y}}=\mathrm{a}+\mathrm{b} 1 \mathrm{X} 1+\mathrm{b} 2 \mathrm{X} 2+\mathrm{b} 3 \mathrm{X} 3$

Dimana:

$\hat{\mathrm{Y}}=$ Kinerja Manajerial $\quad \mathrm{X}_{1}=$ Partisipasi Anggaran

$\mathrm{a}=$ Konstanta

$\mathrm{b}=$ Koefisien regresi

$$
\mathrm{X}_{2}=\text { Komitmen Organsasi }
$$

$\mathrm{X}_{3}=$ Motivasi

\section{HASIL UJI ASUMSI KLASIK}

Uji normalitas berguna untuk menentukan data yang telah dikumpulkan berdistribusi normal atau diambil dari populasi normal. Metode klasik dalam pengujian normalitas suatu data tidak begitu rumit. Berdasarkan pengalaman empiris beberapa pakar statistik, data yang banyaknya lebih dari 30 angka ( $\mathrm{n}>30)$, maka sudah dapat diasumsikan berdistribusi normal. Biasa dikatakan sebagai sampel besar. Uji ini digunakan untuk mengukur data berskala ordinal, interval, ataupun rasio. Model regresi yang baik adalah distribusi data normal atau mendekati normal. Deteksi adanya normalitas yaitu dengan melihat penyebaran data (titik) pada sumbu diagonal dari grafik. 


\section{Uji Normalitas Metode Grafik P-P plot}

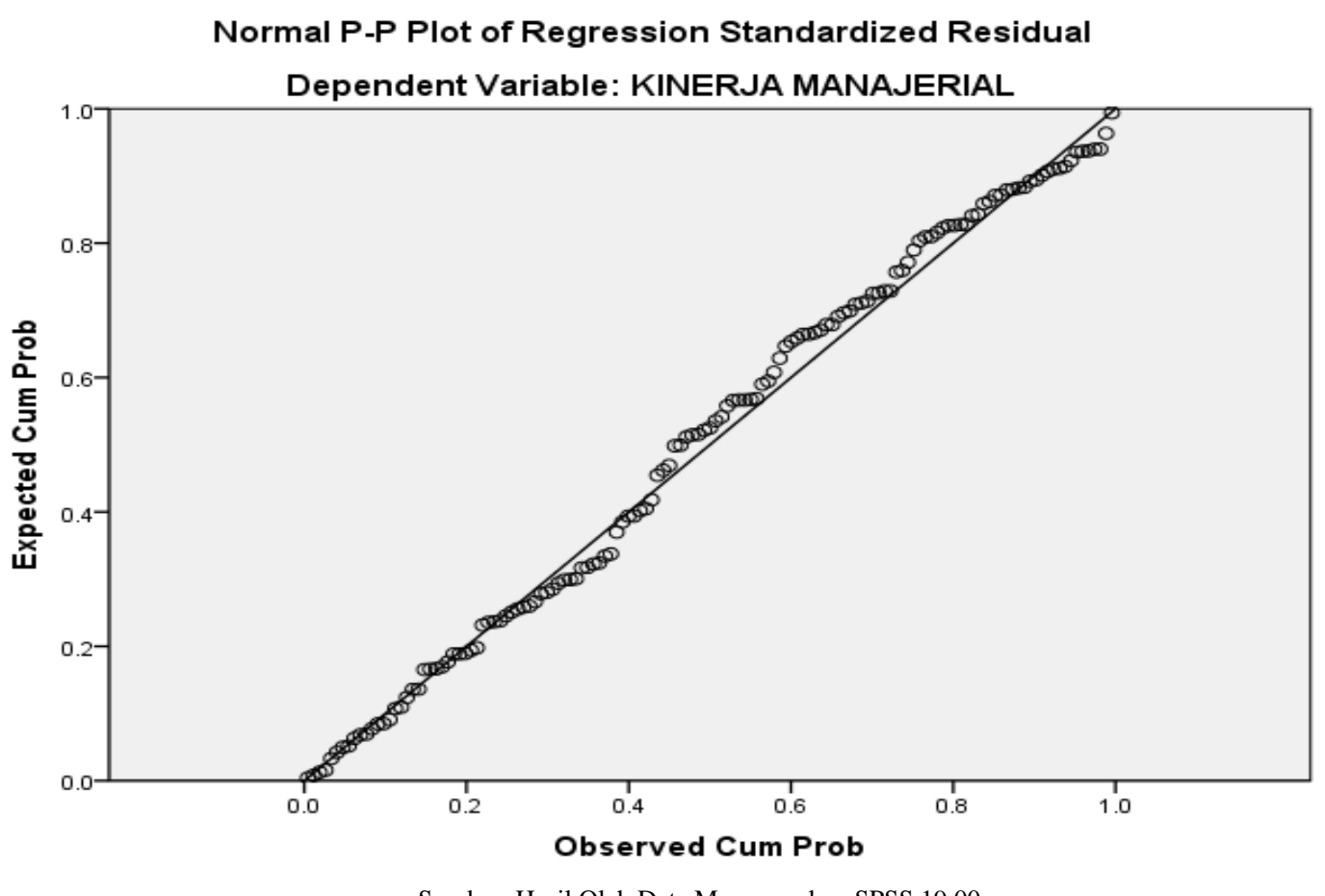

Sumber: Hasil Olah Data Menggunakan SPSS 19.00

Dari grafik di atas dapat diketahui bahwa titik-titik menyebar sekitar garis dan mengikuti garis diagonal, maka model regresi tersebut telah memenuhi uji normalitas karena telah terdistribusi secara normal.

Uji autokorelasi bertujuan untuk menguji apakah dalam model regresi linear terdapat korelasi antara kesalahan penganggu pada periode $t$ dengan kesalahan pengganggu pada periode t-1. autokorelasi timbul karena observasi yang berurutan sepanjang waktu berkaitan satu sama lainnya. Masalah ini timbul karena residual tidak bebas dari satu observasi ke observasi lainnya. Hal ini seirng muncul pada data runtut waktu.

\section{Tabel autokorelasi}

Model Summary

\begin{tabular}{|c|c|c|c|c|c|}
\hline Model & $\mathrm{R}$ & R Square & $\begin{array}{l}\text { Adjusted R } \\
\text { Square }\end{array}$ & $\begin{array}{l}\text { Std. Error of the } \\
\text { Estimate }\end{array}$ & Durbin-Watson \\
\hline 1 & $.875^{a}$ & .766 & .760 & 7.797 & 1.929 \\
\hline
\end{tabular}

Sumber: Hasil Olah Data Menggunakan SPSS 19.00

Pada output SPSS didapat angka DW sebesar 1,929 angka tersebut berada di antara 1,541 dengan 2,46 yang berarti tidak terjadi autokorelasi.

Uji heterokedastisitas dipergunakan untuk menguji apakah dalam model regresi terjadi ketidaksamaan varians dari residual satu pengamatan ke pengamatan lainnya. Jika varians dari residual satu pengamatan ke pengamatan lainnya tetap, hal ini disebut sebagai 
homoskedastisitas. Kebanyakan data cross section mengandung situasi heteroskesdastistis karena data ini menghimpun data yang mewakili berbagai ukuran (kecil, sedang dan besar).

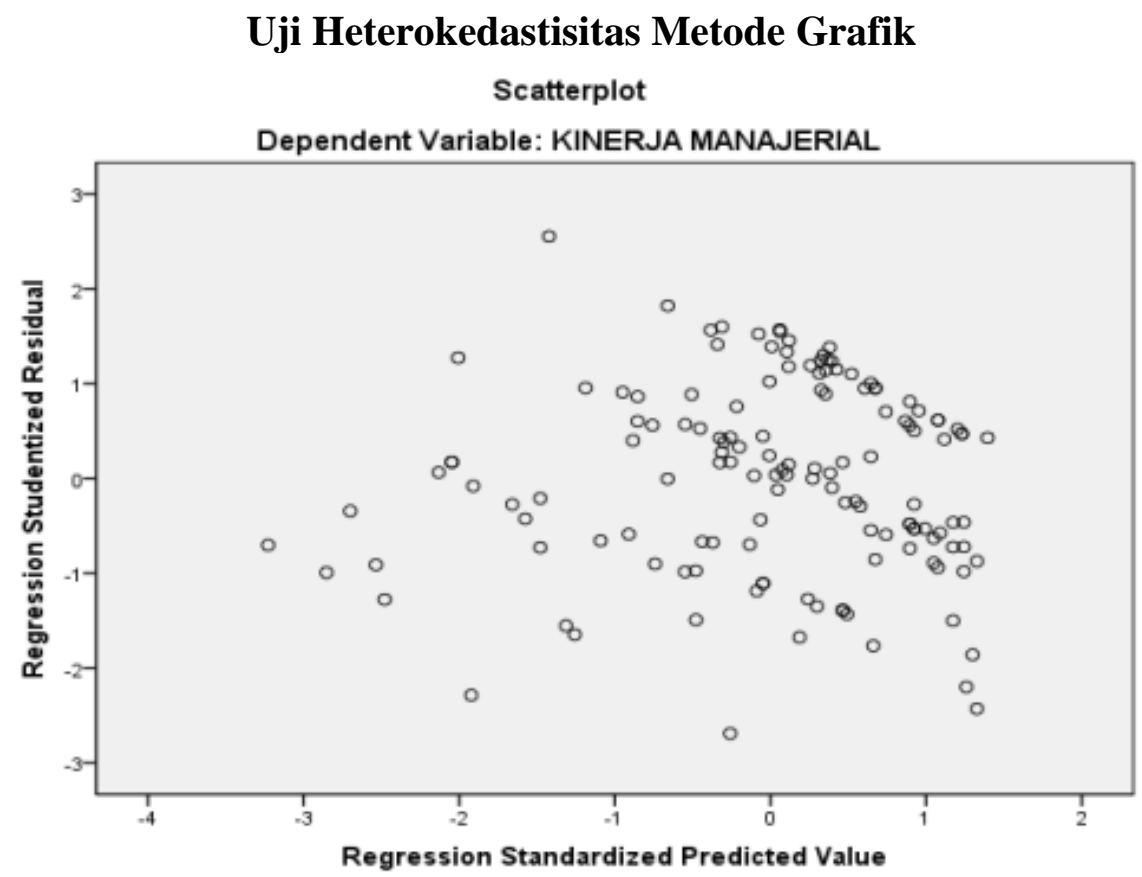

Sumber: Hasil Olah Data Menggunakan SPSS 19.00

Hasil pengolahan data pada gambar terlihat bahwa titik-titik menyebar dengan pola yang tidak jelas di atas dan di bawah angka 0 pada sumbu Y. Hal ini menunjukkan bahwa tidak terjadi masalah heterokedastisitas pada model regresi

Uji multikolinearitas muncul jika terdapat hubungan diantara beberapa variabel atau semua variabel independen dalam model regresi. Model regresi yang baik seharusnya tidak terdapat problem multikolinearitas atau tidak terdapat korelasi antar variabel independen. Metode yang digunakan untuk mendeteksi adanya multikolinearitas adalah dengan melihat besaran korelasi antar variabe independen. Hal ini dapat dilihat dari nilai Variance Inflation Factor (VIF) atau tolerance value.

Tabel Uji Multikolinearitas

\begin{tabular}{|l|r|r|}
\hline \multicolumn{1}{|c|}{ Keterangan } & Nilai Tolerance & Nilai VIF \\
\hline Partisipasi Anggaran & 0.428 & 1.002 \\
\hline Komitmen Organisasi & 0.424 & 1.002 \\
\hline Motivasi Sumber: Hasil Olah Data Menggunakan SPSS 19.00 \\
\hline \multicolumn{2}{|c|}{ S }
\end{tabular}

Pada tabel tersebut menunjukkan semua angka VIF variabel model regresi lebih kecil dari 10 (VIF < 10), hal ini menunjukkan model regresi linier berganda tidak mempunyai persoalan multikolinearitas. Hasil perhitungan nilai tolerance juga menunjukkan tidak ada varibel independen yang nilainya kurang dari 0,1 (tolerance $<0,1$ ), yang berarti tidak ada korelasi antar variabel independen yang nilainya lebih dari 95\%, Hal ini berarti seluruh variabel independen yang digunakan terbebas dari penyakit multikolineritas.

Adapun data yang diperoleh dari pendekatan empiris dianalisis secara kuantitatif dengan menggunakan teknik pengujian uji multiple regression (regresi berganda). Penggunaan model uji multiple regression akan membantu untuk melakukan identifikasi 
setiap variasi independen yang diteliti, sehingga nampak variabel mana dari variabel bebas yang sangat berpengaruh terhadap dependen variabel.

Tabel Analisis Regresi Linier Berganda

\begin{tabular}{|c|c|c|c|c|}
\hline \multicolumn{2}{|c|}{ Model } & \multicolumn{2}{|c|}{ Unstandardized Coefficients } & $\begin{array}{c}\text { Standardized } \\
\text { Coefficients }\end{array}$ \\
\hline \multirow[t]{4}{*}{1} & (Constant) & 9.570 & 4.545 & \\
\hline & PARTISIPASI ANGGARAN & 2.132 & .344 & .394 \\
\hline & KOMITMEN ORGANISASI & 1.348 & .381 & .227 \\
\hline & MOTIVASI & 1.747 & .286 & .364 \\
\hline
\end{tabular}

Sumber: Hasil Olah Data Menggunakan SPSS 19.00

Nilai persamaan regresi linier berganda sebagai berikut:

$$
\begin{aligned}
& \mathrm{Y}=\mathrm{a}+\mathrm{b} 1 \mathrm{X} 1+\mathrm{b} 2 \mathrm{X} 2+\mathrm{b} 3 \mathrm{X} 3+\mathrm{e} \\
& \mathrm{Y}=9.570+2.132 \mathrm{X} 1+1.348 \mathrm{X} 2+1.747 \mathrm{X} 3+\mathrm{e}
\end{aligned}
$$

Setelah dilakukan uji model regresi pada penelitian ini didapatkan hasil analisis data atas variabel independen partisipasi anggaran, komitmen organisasi, motivasi serta variabel dependen adalah kinerja manajerial.

\section{Analisis Koefisien Determinasi}

Pada penelitian ini koefisien determinasi berfungsi untuk mengetahui persentase besarnya pengaruh variabel independen partisipasi anggaran (X1), komitmen organisasi(X2), motivasi (X3) dan dependen kinerja manajerial (Y) hal ini ditunjukkan oleh besarnya koefisien determinasi $\left(\mathrm{R}^{2}\right)$ antara 0 (nol) sampai dengan 1 (satu). Hasil analisis determinasi dapat dilihat pada output Model Summary dari hasil analisis regresi linier berganda.

\section{Analisis Koefisien Determinasi}

Model Summary

\begin{tabular}{l|r|r|r|r|r|}
\hline & Rodel & R Square & $\begin{array}{c}\text { Adjusted R } \\
\text { Square }\end{array}$ & $\begin{array}{c}\text { Std. Error of } \\
\text { the Estimate }\end{array}$ & Durbin-Watson \\
\hline 1 & $.875^{\mathrm{a}}$ & \multicolumn{2}{|c|}{.766} & 7.797 & 1.929 \\
\hline
\end{tabular}
a. Predictors: (Constant), MOTIVASI, PARTISIPASI ANGGARAN, KOMITMEN ORGANISASI
b. Dependent Variable: KINERJA MANAJERIAL

Sumber: Hasil Pengolahan Data SPSS

Berdasarkan tabel di atas dapat dilihat hasil analisis koefisien determinasi secara simultan sebagai berikut:

a. Nilai R sebesar 0.875 dan nilai Adjusted R Square sebesar 0,760. Semakin besar nilai Adjusted R Square mendekati angka 1 (satu), maka variabel independen yaitu motivasi, partisipasi anggaran, komitmen organisasi berpengaruh semakin kuat terhadap variabel dependen yaitu kinerja manajerial.

b. Nilai Adjusted R Square sebesar 0.760 atau $76 \%$ ini menunjukkan bahwa kontribusi persentase pengaruh variabel independen yaitu partisipasi anggaran, komitmen organisasi, motivasi dengan variabel dependen yaitu kinerja manejerial secara simultan sebesar $76 \%$, sedangkan yang sebesar $24 \%$ dipengaruhi oleh faktor lain di luar ketiga variabel tersebut.

c. Uji Hipotesis Secara Parsial (t-Test) 
d. Pada penelitian ini uji $\mathrm{t}$ digunakan untuk mengetahui apakah variabel independen yang terdiri dari variabel partisipasi anggaran, komitmen organisasi, motivasi secara parsial memiliki pengaruh terhadap variabel dependen yaitu variabel kinerja manajerial (Y)

\section{e. Distribusi t variabel}

\begin{tabular}{|c|c|c|c|c|c|c|}
\hline \multicolumn{7}{|c|}{ Coefficients $^{\mathrm{a}}$} \\
\hline \multicolumn{2}{|c|}{ Model } & \multicolumn{2}{|c|}{$\begin{array}{l}\text { Unstandardized } \\
\text { Coefficients }\end{array}$} & $\begin{array}{l}\text { Standardized } \\
\text { Coefficients }\end{array}$ & $\mathrm{T}$ & Sig. \\
\hline 1 & (Constant) & 9.570 & 4.545 & & 2.106 & .037 \\
\hline & PARTISIPASI ANGGARAN & 2.132 & .344 & .394 & 6.193 & .000 \\
\hline & KOMITMEN ORGANISASI & 1.348 & .381 & 227 & 3.541 & .001 \\
\hline & MOTIVASI & 1.747 & .286 & .364 & 6.111 & .000 \\
\hline
\end{tabular}

Sumber: Hasil Pengolahan Data SPSS

Pengujian secara parsial partisipasi anggaran menunjukkan bahwa nilai t hitung sebesar 6.193. Nilai t hitung positif, artinya pengaruh yang terjadi adalah positif. Hal ini menunjukkan bahwa partisipasi anggaran akan meningkatkan kinerja manajerial, tingkat signifikansi < 0,05. Hasil ini menunjukkan bahwa variabel bebas yaitu partisipasi anggaran secara parsial mempunyai pengaruh yang signifikan terhadap variabel terikat yaitu kinerja manajerial.

Pengujian secara parsial komitmen organisasi menunjukkan bahwa nilai t hitung sebesar 3.541. Nilai t hitung positif, artinya pengaruh yang terjadi adalah positif. Hal ini menunjukkan bahwa komitmen organisasi akan meningkatkan kinerja manajerial, tingkat signifikansi $<0,05$. Hasil ini menunjukkan bahwa variabel bebas yaitu komitmen organisasi secara parsial mempunyai pengaruh yang signifikan terhadap variabel terikat yaitu kinerja manajerial.

Pengujian secara parsial motivasi menunjukkan bahwa nilai t hitung sebesar 6.111. Nilai $\mathrm{t}$ hitung positif, artinya pengaruh yang terjadi adalah positif. Hal ini menunjukkan bahwa motivasi akan meningkatkan kinerja manajerial, tingkat signifikansi $<0,05$. Hasil ini menunjukkan bahwa variabel bebas yaitu motivasi secara parsial mempunyai pengaruh yang signifikan terhadap variabel terikat yaitu kinerja manajerial.

\section{Uji Hipotesis Secara Simultan (F-Test )}

Variabel independen pada penelitian ini lebih dari satu variabel, maka uji hipotesis menggunakan F-Test. Uji F digunakan untuk menguji apakah variabel independen yaitu variabel partisipasi anggaran, komitmen orgnisasi, motivasi, secara simultan berpengaruh dengan variabel dependen yaitu kinerja manajerial.

\section{f. Hasil Uji Hipotesis Secara Simultan (F-Test)}

ANOVA

\begin{tabular}{|ll|r|r|r|r|r|}
\hline Model & & Sum of Squares & Df & \multicolumn{1}{c|}{$\begin{array}{c}\text { Mean } \\
\text { Square }\end{array}$} & \multicolumn{1}{c|}{ F } & Sig. \\
\hline 1 & Regression & 26813.282 & 3 & 8937.761 & 147.014 & $.000^{\mathrm{a}}$ \\
& Residual & 8207.351 & 135 & 60.795 & & \\
& Total & 35020.633 & 138 & & & \\
\hline
\end{tabular}

a. Predictors: (Constant), MOTIVASI, PARTISIPASI ANGGARAN, KOMITMEN ORGANISASI

b. Dependent Variable: KINERJA MANAJERIAL 
Hasil pengujian secara bersama-sama menunjukkan nilai Fstat sebesar 147.014 dengan nilai sig sebesar 0.000 , hal ini memiliki pengertian variabel independent yang digunakan dalam penelitian ini signifikan dalam mempengaruhi variabel dependen, karena nilai sig dari Fstat $0.000<0.05$ maka Ho ditolak, artinya seluruh variabel independen motovasi, partisipasi anggaran, komitmen organisasi memiliki pengaruh terhadap kinerja manajerial secara siginifikan pada tingkat kepercayaan sebesar $95 \%$.

\section{H1: Terdapat pengaruh positif partisipasi anggaran terhadap kinerja manajerial}

Partisipasi anggaran berpengaruh positif terhadap kinerja manajerial. Berdasarkan nilai $t$ hitung sebesar 6.193 dengan nilai signifikansi $0.000<0,05$. Nilai t hitung positif, artinya pengaruh yang terjadi adalah positif. Semakin baik partisipasi anggaran yang dimiliki PT.ZZZ maka kinerja manajerial semakin meningkat.

Hasil penelitian ini membuktikan kebenaran hipotesis ada pengaruh positif antara partisipasi anggaran terhadap kinerja manajerial. Hasil penelitian ini sejalan dengan penelitian Matthew A.Abata (2014) yang di lakukan pada perusahaan makanan di Nigerian menunjukkan bahwa Partisipasi anggaran berpengaruh terhadap kinerja manajerial. Penelitian ini di dukung oleh Radia othman dan Ida haryanti (2012) yang di lakukan di sector pemerintahan malaysia menunjukkan bahwa partisipasi anggaran bberpengarih terhadap kinerja manajerial. Amertadewi Dwirandra (2013) yang di lakukan di PT Bank Pembangunan Daerah Bali, Hasil penelitian menunjukan secara parsial terdapat pengaruh signifikan antara partisipasi anggaran terhadap kinerja manajerial. Moheri Dan Arifah (2015) di lakukan di PT perusahaan manufaktur di semarang, Hasil penelitian menunjukan secara parsial terdapat pengaruh signifikan antara partisipasi anggaran terhadap kinerja manajerial.

Penelitian ini tidak sejalan dengan Owusu et al (2014) dilakukan di univeristas ghana menunjukkan partisipasi anggaran tidak berpengaruh terhadap kinerja manajerial. Osama et al (2013) dilakukan di universitas Jordania Partisipasi anggaran tidak berpengaruh terhadap kinerja manajerial

\section{$\mathrm{H} 2$ : Terdapat pengaruh positif komitmen organisasi terhadap kinerja manajerial}

Komitmen organisasi berpengaruh positif terhadap kinerja manajerial. Berdasarkan nilai $t$-hitung sebesar 3.541 dengan nilai signifikansi $0.001<0,05$. Nilai t hitung positif, artinya pengaruh yang terjadi adalah positif. Semakin baik komitmen organisasi pegawai di PT ZZZ dapat membuat kinerja manajerial semakin meningkat

Hasil penelitian ini membuktikan kebenaran hipotesis ada pengaruh positif antara komitmen organisasi terhadap kinerja manajerial. Hasil penelitian ini sejalan dengan penelitian Radia Othman dan Ida haryanti (2012) yang di lakukan pada sector pemerintahan di Malaysia menunjukkan bahwa komitmen organisasi berpengaruh positif terhadap kinerja manajerial, Rumasukun, et al (2015) yang dilakukan perusahaan komunikasi dan teknologi provinsi papua, menyatakan komitmen organisasi berpengaruh terhadap kinerja manajerial

\section{H3: Terdapat pengaruh positif motivasi terhadap kinerja manajerial}

Motivasi berpengaruh positif terhadap kinerja manajerial. Berdasarkan nilai $t$-hitung sebesar 6.111 dengan nilai signifikansi $0.000<0,05$. Nilai t hitung positif, artinya pengaruh yang terjadi adalah positif. Semakin baik motivasi pegawai PT. ZZZ membuat kinerja manajerial semakin meningkat

Hasil penelitian ini membuktikan kebenaran hipotesis ada pengaruh positif antara motivasi terhadap kinera manajerial. Hasil penelitian ini sejalan dengan penelitian 
Moheri Dan Arifah (2015), Rumasukun, et al (2015) hasil penelitiannya menunjukkan bahwa motivasi mempuyai pengaruh positif terhadap kinerja manajerial.

\section{KESIMPULAN DAN SARAN}

Berdasarkan hasil penelitian pengaruh partisipasi anggaran, komitmen organisasi dan motivasi terhadap kinerja manajerial PT. ZZZ, dapat disimpulkan bahwa:

Variabel partisipasi anggaran berdasarkan pandangan karyawan yang diteliti menunjukkan hasil bahwa variabel tersebut mempunyai pengaruh positif dan signifikan terhadap kinerja manajerial. Hal ini menunjukkan bahwa partisipasi anggaran dalam lingkungan kerja PT. ZZZ sudah cukup baik sehingga manajer dapat memberikan kinerja yang baik kepada perusahaan

Variabel komitmen organisasi berdasarkan pandangan karyawan yang diteliti menunjukkan hasil bahwa variabel tersebut mempunyai pengaruh positif dan signifikan terhadap kinerja manajerial. Hal ini menunjukkan bahwa komitmen organisasi dalam lingkungan kerja PT. ZZZ sudah cukup baik sehingga manajer memiliki rasa puas dan menunjukkan keyakinan dan dukungan yang kuat terhadap sasaran dan nilai yang ingin dicapai oleh perusahaan.

Variabel motivasi berdasarkan pandangan karyawan yang diteliti menunjukkan hasil bahwa variabel tersebut mempunyai pengaruh positif dan signifikan terhadap kinerja manajerial. Motivasi yang diberikan perusahaan memiliki tujuan untuk meningkatkan semangat kerja karyawannya. Penelitian ini menunjukkan bahwa motivasi yang diberikan oleh PT. ZZZ sudah sesuai dengan kebutuhan manajer dan mampu untuk meningkatkan kemampuan dan semangat kerja karyawan.

Hasil penelitian menunjukkan hasil persamaan linier sebagai berikut :

$$
\mathrm{Y}=9.570+2.132 \mathrm{X} 1+1.348 \mathrm{X} 2+1.747 \mathrm{X} 3+\mathrm{e}
$$

Berdasarkan hasil penelitian yang ada, maka dapat diberikan beberapa saran yaitu, bagi manajemen perusahaan, sebaiknya dapat meningkatkan lagi variabel komitmen organisasi. Berdasarkan regresi linier yang dihasilkan, nilai koefisien yang dihasilkan variabel tersebut cukup kecil jika dibandingkan dua variabel lainnya. Jadi dapat disimpulkan bahwa sensitifitas variabel ini terhadap kinerja manajerial masih tergolong rendah jika dibandingkan kedua variabel lainnya. Meskipun tidak terlihat, namun komitmen organisasi memainkan peran yang cukup penting bagi karyawan khususnya para manajer, karena berkaitan dengan "kenyamanan kerja".

Bagi peneliti lain, mungkin dapat mencari variabel lain yang diduga dapat memberikan pengaruh terhadap kinerja manajerial. Dari hasil penelitian ini menunjukkan bahwa nilai $\mathrm{R}^{2}$ sebesar $76 \%$. Hal ini menunjukkan bahwa masih ada variabel lain yang mungkin berpengaruh terhadap kinerja manajerial, misalnya variabel lingkungan kerja, variabel pola kepemimpinan, dan variabel kedisiplinan. Dengan ditemukannya variabel lain yang berpengaruh terhadap kinerja maka perusahaan dapat lebih terinci untuk dapat menyusun kebijakan-kebijakan yang dapat meningkatkan kinerja manajerial. 


\section{DAFTAR PUSTAKA}

A.F.Stoner James, DKK, 1996, Manajemen, Edisi Indonesia, Penerbit PT. Prenhallindo, Jakarta

Angle, H.L. and J.L. Perry, (1981). An Empirical Assessment of organizational Commitment and Organizational Effectivenes5. Administrative Science Quarterly26, pp. 1-14.

Armatrong, M and Baron, A. 1998.Performance Management - The New Realities. London: Institute of Personnel and Development.

Bastian, Indra. 2006. Akuntansi Sehtor Publik: Suatu Pengantar. Penerbit Erlangga. Jakarta.

Bambang Prasetyo dan Lina Miftahul Jannah, Motode Penelitian Kuantitatif, Rajawali Pers, Jakarta, 2011.

Brownell, P., dan McInnes, M., 1986, "Budgetary Participation, Motivation, and Managerial Performance." The Accounting Review (October), Vol. LXI, No. 4.

Ghozali, Imam 2011. "Aplikasi Analisis Multivariate Dengan Program SPSS". Semarang: Badan Penerbit Universitas Diponegoro

Haryanti and Othman, R. 2012. Budgetary Participation: How It Affects Performance and Commitment. Accountancy Business and the Public Interest.

Lubis, Arfan Ilkhsan. 2011. Akuntansi Keperilakuan. Edisi 2. Jakarta: Salemba

Milani, K.W. (1975). "The Relationship of Participation in Budget-Setting to Industrial Supenvisor Performance and Attitudes: a Field Study", The Accounting Review, 50(2), pp. 274-284

Mulyadi. 2014. Sistem Akuntansi. Yogyakarta: Salemba Empat

Malayu S.P. Hasibuan, 2007, Manajemen Sumber Daja Manusia, Jakarta, Bumi Aksara.

Mardiasmo. (2006). Perwujudan Transparanai dan Akuntabilitas Publik Melalui Akuntansi Sektor Publikn Suatu Sarana Good Govemance.Jwnal Akuntansi Pemerintahan, 2: 1. (1-17).
Moheri, Yoyon, and Dista Amalia Arifah, 2015,"Pengaruh Partisipasi Anggaran Terhadap Kinerja Manajerial." Jumal Ekonomi \& Bisnis 16.1 (2015): 86-93.

Nouri, H. dan R. J. Parker. 1998. The Relationship Betwesh Budget Participation And Job Performance: The Roles Of Budget Adequacy And Organizational Commitment. Accounting, Organization and Society. Vol 23. No5/6 pp. $467-483$

Nuriski, Amalia. 2010. Analisis Pengaruh Karakteristik/ Anggaran terhadap Kinerja Manajerial (Studi Kasus pada Credit Union Mandiri Jawa Timuv). Skripsi Fakultas Ekonomi Universitas Jember

Ompusunggu, K.B. dan I.R. Bawono. 2007. 'Pengaruh Partisipasi Anggaran dan Job Relevant Information (JRI) terhadap Informasi Asimetris". Jurnal Akuntansi dan Keuangan Sektor Publik, Vol 08, No. 01, Februari 2007

Robbins,Stephen P. and Coulter,Mary. 2012. Management. New Jersey: Pearson Education, Inc.

R.Terry, George dan Leslie W.Rue. Dasay-Dasar Manqjemen,(Jakarta: Bumi Aksara, 2010)

Sevilla, Consuelo G. et al. 2006. Pengantar Metode Penelitian.UI Press, Jakarta.

Sopiah. 2008. Perilaku Organisasi, Yesyakarta. Andi

Sugivono. 2008. Metode Penelitian Bisnis. Alfabeta. Bandung

Sumarno, J. 2005. Pengaruh Komitmen Organisasi dan Gaya Kepemimpinan terhadap Hubungan antara Partisipasi Anggaran dan Kinerja Manajerial. Jumal Bisnis Strategi, Vol. 14, no. 2, Desember 2005.Time 
